\title{
E SE?
}

Renata Ribeiro Costa Machado

DOI: http://dx.doi.org/10.18616/intcov47

E se eu tivesse usado máscara?

Ah, mas foi só um dia.

E se eu tivesse lavado bem as mãos?

Ah, mas foi só uma vez.

E se eu tivesse ido sozinho ao mercado?

$\mathrm{Ah}$, mas não foi rebeldia.

E seu tivesse ficado em casa?

Ah, não ficaria doente, TALVEZ.

Talvez não estaria no hospital,

Na solidão,

Na depressão,

Sem respiração,

Talvez não estaria sofrendo

Morrendo

Morrend

Morren

A

$\mathrm{R}$

A

O

Morre

Morr

Mor

Mo

U

M 